\title{
Self-employment as a Form of Realisation of the Right to Freely Chosen Employment: Problems of Legal Regulation
}

\author{
Elena Orlova ${ }^{1},{ }^{*}$ Konstantin Krylov ${ }^{2}$, Tamara Soshnikova ${ }^{3}$ \\ ${ }^{1}$ Tambov State Technical University, Tambov, Russia \\ ${ }^{2}$ Moscow State Law University (MGUA), Moscow, Russia \\ ${ }^{3}$ Moscow Humanitarian University, Moscow, Russia \\ *Email: elenaorlowa@yandex.ru
}

\begin{abstract}
The article is devoted to studying the problems of legal regulation of self-employment as a form of realising the right to freely chosen employment. It is noted that recent changes in the legislation of the Russian Federation have provoked positive trends in the "withdrawal of the self-employed from the shadow economy," however, there are still many unresolved problems. The author of the article conducts a study of some types of activities that can be attributed to the institute of self-employment. The author analyses narrow and broad approaches to self-employment, distinguishing between self-employment and entrepreneurship. The correlation of the concepts of "self-employed" and "self-supporting persons" is analysed, signs of self-employment as an activity are identified, and the circle of persons belonging to the self-employed who have the right to conduct the types of activities specified in the legislation is designated. New forms of self-employment are being investigated, which have been developing more and more recently. Summing up the research, it is proposed to consolidate the relevant norms in Russian legislation's legal regulation of self-employment.
\end{abstract}

Keywords: Self-employed, Self-supporting work, Entrepreneurial activity, Individual entrepreneurs, Unemployment, Forms of self-employment, Signs of self-employment, The legal status of the self-employed.

\section{INTRODUCTION}

Modern transformation processes in the economy (increased requirements for the level of competence of employees, the introduction of innovations and digital technologies) impact the development of the labour market; it becomes more flexible, more mobile, new forms and types of employment appear. Recently, the spread of the new COVID-19 coronavirus infection in Russia has developed self-employment as a new form of labour relations.

The establishment of the right-wing status of the self-employed progressed rather slowly since the work mainly had an economic bias. However, recent changes in legislation have generated a new wave of scientific research on the development of self-employment and changing the status of the self-employed themselves.
The works made a significant contribution to the development of the problems of self-employment by Russian scientists V.V. Kuznetsova [1], N.V. Lapteva, M.V. Rybkina, T.I. Bogdanova, Yu.A. Rosloy [2], V.M. Zherebina [3], A.N. Romanova, L.Yu. Malinin and foreign researchers Banerjee Pallavi [4], Chen Martha Alter [5], Laferriere Alex [6], Lomax Richard [7].

It is important to note that recent changes in the legislation of the Russian Federation have provoked positive trends in the "withdrawal of the self-employed from the shadow economy." Nevertheless, there are still many unresolved problems associated primarily with the derivation of a full legal definition of self-employment, which would affect the possibility of determining the list of forms of self-employment and persons belonging to the self-employed. Since this list is still rather vague, it is difficult to give a legal assessment of some types of 
activities that can be attributed to the institution of selfemployment.

\section{RESEARCH METHODOLOGY}

The methodological basis of the research is based on the application of various general scientific techniques and methods of scientific cognition (axiomatic method, methods of analysis and synthesis, dialectical method, formal legal method, method of interpretation of legal norms).

\section{DISCUSSION OF THE STUDY RESULTS}

In the current version of Article 2 of the Law of the Russian Federation of April 19, 1991 No. 1032-1, the circle of persons belonging to employed citizens is defined, and there is no such category as self-employed [8]. Although there has always been a category of selfemployed in Russia, who appeared in the Employment Law of the Russian Federation (in the 90s), then disappeared again. The category of self-employed citizens traditionally included persons who opened their businesses and registered as individual entrepreneurs. Such unemployed citizens have always been provided with state support in the employment service bodies in the form of assistance in drawing up a business plan and issuing subsidies (financing) for starting their own business. In fact, the self-employed were identified with citizens registered following the established procedure as individual entrepreneurs without forming a legal entity. This was also indicated by some regulatory legal acts [9]. An individual entrepreneur is considered employed even if his activity did not bring income. However, the wording of sub-clause 7 , clause 1, Article 7 of the Employment Law in the Russian Federation makes it clear that the legislator distinguishes the categories of "employment", "self-employment", and "entrepreneurship" [8].

Recently, to expand the entrepreneurial activity of citizens, reduce unemployment and informal employment in the labour market, the state has created favourable conditions by establishing a special tax on professional income established by Federal Law No. 422-FZ on November 27, 2018 "On experimenting with establishing a special tax regime "Tax on professional income" in the federal city of Moscow, in the Moscow and Kaluga regions, as well as in the Republic of Tatarstan (hereinafter - Federal Law No. 422) [10], and also designated the circle of persons entitled to conduct the types of activities specified in the legislation. The absence of the concept of "self-employment" in the adopted Federal Law No. 422 is quite logical since the norms of tax law do not regulate the activity of a selfemployed person. Therefore, it would be correct to fix the concept of "self-employed" in the Law on Employment in the Russian Federation. This would solve many problems, including those related to protecting the rights of self-employed citizens in the courts (for example, issues of jurisdiction).

Thus, we can conclude the ratio of employment and self-employment as a part and a whole. It should also be noted that self-employment has signs of both formal and informal employment; it is attributed to the latter, including, for example, helping family members, working without registration as individual entrepreneurs; employed in their household, etc.

Even though self-employment is a type of employment, modern legislation has not yet been brought into line with existing realities. Therefore, very often, small businesses and self-employment are challenging to distinguish. Moreover, the activities of the majority of the self-employed can be attributed to micro-entrepreneurship. According to the broad approach that E.A. Abramova adheres to, the selfemployed should include all who work not on a hiring base [10]. N.M. Volovskaya, L.K. Plyusnina, A.V. Rusin, A.V. Inozemtseva consider self-employment primary for entrepreneurship [12]. Followers of the narrow approach point to the main difference between self-employment and entrepreneurship - personal labour participation [13].

Federal Law No. 422 also indicates the absence of employees. All these signs make it possible to distinguish between "self-employment" and "entrepreneurial activity", but at the same time, it is impossible to deny their relationship.

In this regard, there is a need to determine the content of self-employment and the factors of its development to highlight its signs.

In 2017, a draft of Law on Employment of the Russian Federation was developed, where the concept of self-employment was defined in Article 2, and the criteria for this concept were defined: "Self-employed are individuals who independently carry out at their risk activities to provide services to other individuals aimed at systematic profit and based solely on personal labour participation, including during time free from fulfilling obligations under an employment contract. At the same time, the self-employed cannot be registered as individual entrepreneurs. It is also indicated that any person over the age of 16 can be self-employed, who will receive the status of self-employed after sending a notification to the tax inspectorate following the legislation of the Russian Federation on taxes and fees that he is engaged in work related to self-employment" [12]. It is impossible to agree that only the activity of providing services to other individuals is considered the activity of a self-employed person, and providing services to legal entities cannot be recognised as such.

Currently, self-employment is a broad phenomenon with no clear criteria fixed in legislation. 
From the standpoint of economic scientists, selfemployment as a phenomenon has the following signs (features). For example, A.E. Kotlyar notes that "selfemployment as such bypasses the labour market since, in the labour market, wage labour acts as a commodity, and in self-employment, the carrier of labour and the owner of jobs is one person - the self-employed" [14]. M.S. Toksanbayeva notes that "in self-employment, the disposal of property is inseparable from its ownership [15]. In this case, all actions will be carried out on their behalf, which distinguishes self-employment from an institutional unit." Therefore, the self-employed is the owner, the manager, and the executor simultaneously. However, it is difficult to see the line between entrepreneurship and self-employment with such a characteristic of the self-employed.

Thus, self-employment is defined as an independent activity of an individual or an individual entrepreneur who does not have an employer and employees, carried out at their own risk and based on personal labour, to satisfy personal, domestic or other needs.

In addition, new forms of self-employment have been developing more and more recently: innovative self-employment, Internet employment and freelancing.

Innovative self-employment is inextricably linked with the innovation process, introducing new technologies requiring specialists with limited knowledge. This type of self-employment differs from traditional self-employment primarily by the purpose and nature of the activity. If self-employment aims to obtain primary or additional income, then innovative self-employment is aimed at acquiring new knowledge, developing new technologies, improving existing ones. A striking example is freelancing, which is very similar to innovative self-employment. They are attended by qualified professionals who come to self-employment to meet their creative and social needs. In this case, the self-employed remain satisfied with the process of creating something new, a free work schedule and the absence of corporate frameworks.

In addition, organisations hiring freelancers do not need to create new jobs and incur additional costs. Individuals employing such a self-employed category will be provided with the best quality personalised services.

In most countries of the world, self-employment provided by digital platforms (Internet employment) is of interest and concern. From one point of view, this type of self-employment is a more flexible mechanism for workers experiencing various types of discrimination in the labour market due to a person's gender, age, and physical abilities. But, on the other hand, it is considered a form of precarisation of the labour force. Nevertheless, it is noted that the high growth of the self-employed exceeds the number of digital and gig workers. It seems that the relationship between innovation and self-employment influences this trend.

\section{CONCLUSIONS}

Thus, the institute of legal regulation of selfemployment in Russia is at the beginning of its development. Summing up my research, it should be noted that it would be advisable to fix the following norms in the Employment Law of the Russian Federation:

- An able-bodied person of working age can obtain the status of a self-employed person after he registers as a self-employed person.

- Persons who are not individual entrepreneurs and "independently carry out activities based on personal labour participation aimed at earning (labour income), approved by the list of activities (works, services) that self-employed persons can engage in, may be registered as self-employed persons."

- Registration of self-employed persons is carried out in a simplified manner under the legislation.

Persons registered as self-employed persons are not entitled to use employees' work in their activities and have an employer. In case of non-compliance with these requirements, self-employed persons lose the status of self-employed persons.

\section{AUTHOR'S CONTRIBUTION}

The article was published by 3 authors Orlova E.E., Krylov K.D., Soshnikova T.A. the author's contribution is $0.25 \mathrm{pp}$.

\section{REFERENCES}

[1] V.V. Kuznetsov, Rural self-employment [Cel'skaya samozanyatost'] // Bulletin of the Ulyanovsk State Technical University [Vestnik Ul'yanovskogo gosudarstvennogo tekhnicheskogo universiteta] 1 (2001) 82-90.

[2] T.I. Bogdanova, Yu.A. Roslaya, Features of income taxation of self-employed citizens [Osobennosti nalogooblozheniya dohodov samozanyatyh grazhdan] // Development of theory and practice of social and economic systems management [Razvitie teorii i praktiki upravleniya social'nymi i ekonomicheskimi sistemami] 8 (2019) 10-12.

[3] V.M. Zherebin, Personal subsidiary farms of the population: state and prospects [Lichnye podsobnye hozyajstva naseleniya: sostoyanie i perspektivy] // Statistics issues [Voprosy statistiki] 10 (2004) 55-63. 
[4] Banerjee Pallavi, Subversive Self-Employment: Intersectionality and Self-Employment Among Dependent Visas Holders in the United States, 2018 [Electronic resource]. URL: https://proxylibrary.hse.ru:2183/doi/full/10.1177/0 002764218793685 (accessed: 10/26/2021)

[5] Chen Martha Alter, Madhav Roopa, Sankaran Kamala. Legal reforms for the self-employed: three urban cases // Indian Journal of Industrial Relations 50(1) (2014) 133-150 [Electronic resource]. URL: https://proxylibrary.hse.ru:2158/stable/pdf/245470 27.pdf?ab_segments=0\%252Fbasic_SYC$4802 \% 252$ Fcontrol\&refreqid=excelsior $\% 3$ A19009 d40ad602e3b1cc84969ef792204 (accessed: 10/26/2021).

[6] Laferriere Alex, Maritz Richard. Entrepreneurship and self-employment for people with disabilities, pp. 45-54 [Electronic resource]. URL: https://proxylibrary.hse.ru:2183/doi/full/10.1177/1 038416216658044 (accessed: 10/26/2021)

[7] Lomax Richard. Self-employment: a view from the inside, pp. 367-369 [Electronic resource]. URL: https://proxylibrary.hse.ru:2183/doi/full/10.1177/1 024258917713844 (accessed: 10/26/2021).

[8] O zanyatosti naseleniya v Rossijskoj Federacii: Zakon RF ot 19 aprelya 1991 g. № 1032-1 // Collection of Legislation of the Russian Federation [Sobranie zakonodatel'stva RF] 17 (1996) 1915.

[9] Interstate standard "GOST 12.0.004-2015, The system of occupational safety standards. Organisation of occupational safety training. General Provisions", approved by Rosstandart Order No. 600-st dated June 9, 2016 "On the Introduction of the interstate standard". DOI: https://docs.cntd.ru/document/456011213

[10] E.A. Abramova, Crisis self-employment in Russia: classification, structure and levels of development [Krizisnaya samozanyatost' v Rossii: klassifikaciya, struktura i urovni razvitiya] // Modern high-tech technologies. Regional attachment [Sovremennye naukoemkie tekhnologii, Regional'noe prilozhenie] 4(32) (2012) 6-15.

[11] V.M. Zherebin, A.H. Romanov, Self-employment of the population. The main ideas and experience of the crisis period [Samostoyatel'naya zanyatost' naseleniya, Osnovnye predstavleniya i opyt krizisnogo perioda], M.: INFRA-M, 2010, 199 p.

[12] N.M. Volovskaya, L.K. Plyusnina, A.V. Rusina, Monitoring the possibility of self-employment development in the Novosibirsk region [Monitoring vozmozhnosti razvitiya samozanyatosti v Novosibirskoj oblasti] //
Economic and social changes: facts, trends, forecast [Ekonomicheskie i social'nye peremeny: fakty, tendencii, prognoz] 4(46) (2016) 130-143.

[13] O.N. Grabova, A.E. Suglobov, Problems of getting out of the shadow of self-employed persons in Russia: risks and ways to overcome them // Economy, Taxes 6 (2017) 108-116.

[14] A.E. Kotlyar, On the concept of the labour market [O ponyatii rynka truda] // Economic issues [Voprosy ekonomiki] 1 (1998) 33-41.

[15] M.S. Toksanbayeva, Self-employment and its contradictions [Samozanyatost' i ee protivorechiya] // Economic science of modern Russia [Ekonomicheskaya nauka sovremennoj Rossii] 3 (1998) 32-45. 